Rev. Józef Łupiński

Cardinal Stefan Wyszyński University in Warsaw

\title{
The Catholic Church in Poland in the Publications of Trybuna Ludu from 1949
}

This journal article discusses articles about the Catholic Church in Poland that appeared in the daily Polish newspaper Trybuna Ludu [The People's Tribune] in 1949. This official publication of the Polish United Workers'Party (Polska Zjednoczona Partia Robotnicza) played an important role in spreading propaganda during communist rule in the Polish People's Republic. During this time, the communist authorities sought to subordinate and neutralize the Church. The year 1949 was particularly important in the history of the relationship between the state and the church because it was then that the communist authorities launched a media offensive against the Catholic Church. While the authorities officially claimed to guarantee religious freedom, they forbid religion from being taught in Polish schools and supported only pro-government "patriot priests." Specifically, Trybuna Ludu reported lawsuits filed against priests who supported the anti-communist underground. An analysis of these articles demonstrates how the communist party used Trybuna Ludu as a tool to spread propaganda.

Key words: Polish People's Republic, Trybuna Ludu, Catholic Church.

\section{Introduction}

After the end of World War II, the Catholic Church in Poland found itself in a new situation as the ruling Communist Party sought to enforce its policy of terror and lawlessness. Despite this, the Church hierarchy attempted to dialogue with the communist authorities in order to achieve peaceful coexistence. Although the government initially tactically tolerated the Church, on September 12, 1946 it declared 
that its 1925 concordat with the Holy See was no longer valid. In turn, the Polish Ministry of Justice established a commission to develop a program to secularize the country. Polish bishops, on the other hand, appointed an episcopal committee to assess the situation in order to respond to the authorities' repressive actions against the Catholic Church. ${ }^{1}$

In their efforts to completely subordinate and neutralize the influence of the Catholic Church in Poland, the authorities controlled and censored publishing houses and detained and accused many priests who supported the anti-communist underground. In 1947, the relationship between the state and the Church deteriorated. In early September of the same year, members of the Catholic hierarchy published a pastoral letter that called the faithful to boycott the atheist press and protest against the communist regime's godless indoctrination of the youth. In turn, the authorities decided to closely monitor the Church, surveil priests who were in contact with the anti-communist underground, counteract the clergy's influence on workers and youth, and restrict the Catholic press. On October 22, 1948, Primate of Poland August Hlond died. The following November, Pope Pius XII appointed Bishop of Lublin Stefan Wyszyński, who the communists recognized as a supporter of Hlond and a critic of the communist political system, as Hlond's successor.

The year 1949 was a critical time in the history of the relationship between the Communist state and the Catholic Church in Poland. During this year, the media commenced an offensive against the Catholic Church, and the communist regime persecuted politically incorrect priests and bishops and supported pro-government "patriot priests."

This publication aims to examine the articles about the Catholic Church in Poland that were published in Trybuna Ludu [The People's Tribune] in 1949 in order to better understand how the communist authorities perceived the Catholic Church in Poland and the expectations they had for this institution.

\section{The Media Within the Communist System}

The press was one of the most important forms of media in totalitarian systems. According to Vladimir Lenin, newspapers should spread the party's propaganda. After the outbreak of the October Revolution in 1917, a press decree disseminated the first ordinance issued on the

A. Dudek, C. Gryz, Komuniści i Kościót w Polsce (1945-1989), Cracow 2003, pgs. 9-16. 
establishment of censorship and the liquidation of all and any publications that criticized the new Polish People's Republic. ${ }^{2}$ Lenin was hostile to Christianity and considered it ideologically inimical to the revolution. On February 2, 1918, the Bolshevik government issued the Decree on the Freedom of Conscience and Clerical and Religious Societies. Although the decree theoretically declared the separation of the Orthodox Church and the Polish state, in reality it prevented the Orthodox Church from functioning normally. Four years later, the Bolsheviks intentionally took advantage of the famine in Russia to definitively liquidate the Orthodox Church and other religious denominations. Particularly severe repressive measures were later enacted against the Roman Catholic Church because it was one of the most significant ideological enemies of communism in Poland. After 1945, the communist leadership made similar attempts to restrict Christian denominations in the satellite countries of the so-called "people's democracy;" these efforts, however, were less radical than in Poland. These restrictions aimed to weaken the Roman Catholic Church's influence on the faithful, deprive the Church in Poland of contact with Rome, and recruit priests who would be willing to collaborate with the communist authorities.

\section{The Polish People's Republic and the Catholic Church}

After the communists took control of Poland and gradually liquidated the Underground State, members of the Roman Catholic Church hierarchy, clergy, and the faithful understood that conflict between the two sides would sooner or later be inevitable. The totalitarian system neither tolerated nor permitted any kind of opposition. Instead, it aimed to subjugate its most dangerous ideological opponent, the Church. Statements made by government representatives at that time clearly and unequivocally confirm this. In his address to the Sejm on November 28, 1947, Prime Minister Józef Cyrankiewicz asserted that the government would not permit the Church to use religious sentiment to arouse political opposition and that most clergy and the faithful should be loyal to state authorities. On January 14 of the following year, the Prime Minister stood before the Sejm and expressed even more explicitly the government's policy regarding the Catholic Church: "The government will not tolerate the aggressive attitude of individual clergymen, especially members of the Church hierarchy, or

History of the Church

H. Karp, Dziennikarz w systemie mediów totalitarnych Polski Ludowej, in: "Media - Kultura - Społeczeństwo," 9-10 (2014-2015), pgs. 51-52. 
attempts to meddle in state affairs and matters of secular public life."3 This was only the beginning of the communist authorities' violent reaction to the Church in Poland. Since such an approach would be met with a strong response on the part of Poles and potentially widen the gap between the Communist Party and society, the communists first sought to disrupt the Polish clergy and establish a group of priests who supported the authorities and who would serve as a political instrument to spread the party's influential propaganda. In short, the government's goal was to create two opposing groups of clergy: the members of the Church hierarchy and "reactionary clergy" who supported the anti-communist underground, opposed the people's state, and supported American agents and fascist Germany, on the one side, and so-called "patriot priests" who were "positively oriented" to the Polish People's Republic, pro-government, close to the people, and disobedient to the hierarchy of the Church, on the other.

In the autumn of 1947, officials from the Ministry of Public Security held an assembly, during which the Director of the 5th Department of the Ministry of Public Security, Julia Brystygierowa, presented an speech entitled "The Clergy's Offensive and Our Response," in which she said:

"Polish clergy play a leading role in opposing the democratic system of the Polish State. [...] Combating the clergy's hostile activity is undoubtedly one of the most difficult tasks. [...] In order to defeat an enemy and, even more, an enemy like the clergy, it is necessary to know them, to understand them."4

Brystygierowa indicated that the Catholic Church was an ideological enemy that engaged in politics, and she consequently ordered the arrest of priests associated with the anti-communist underground; the surveillance of Church institutions such as curias, deaneries, rectories, and religious orders; and the dissolution of Catholic organizations. The Minister of Public Security, Stanisław Radkiewicz, even more bluntly said the following about the Church: "It is necessary to defeat such an enemy as the clergy, [... who make up] the most organized reactionary force against the democratic camp." Others who participated in the

$3 \quad$ K. Kersten, Narodziny system władzy. Poland 1943-1948, Poznań 1990, pgs. 336, $363-364$.

4 Quote from: "Ofensywa kleru a nasze działania," in:Dokumenty do dziejów PRL. Aparat bezpieczeństwa w latach 1944-1956. Taktyka, strategia, metody, Part I, Years 1945-1947, edited by J. Żaryn, Warsaw 1994. 
meeting proposed the detainment of priests and the complete liquidation of Catholic Church in Poland. ${ }^{5}$

The press was to be one of the communist leadership's key instruments in propagandizing the people of Poland. Government media followed the example of Leninist journalism, which demanded absolute loyalty to party's policy. In December 1948, the Polish United Workers' Party (Polska Zjednoczona Partia Robotnicza, PZPR) began publishing its official daily newspaper Trybuna Ludu [The People's Tribune], which reflected the communist party's policy. Both the Central Committee (Komitet Centralny, KC) of the PZPR and the Soviet embassy in Warsaw supervised the newspaper, and communist activists served as its editors-in-chief. The Political Bureau of the KC PZPR treated Trybuna Ludu as a means of disseminating the party's propaganda, presenting party resolutions, and opposing its ideological opponents, especially the Catholic Church. ${ }^{6}$

\section{Religious Education in Polish Schools}

One of the first ways that the authorities targeted the Catholic Church in Poland was to forbid catechesis in public schools. The primary aim was to eliminate the influence that priests and catechists had on youth. Religion also was not taught in specially established schools run by the atheistic Society of Children's Friends (Towarzystwo Przyjaciól Dzieci, TPD). Until the end of the 1940s, religious education in public schools was compulsory, with the exception of TPD-run History schools. In February 1949, however, the Political Bureau decided to hand over the supervision of education to the KC PZPR's Department of Education. On February 2, 1949, the Department of Education decided that all priests, monks, and nuns, and other lay educators who taught secular subjects would be removed from public schools beginning on September 1, 1949. Exactly 239 people were fired, including 35 principals. In the Silesia-Dąbrowa Province, almost all priests who were catechists were removed from primary schools from September 1948 until January 1949. In other schools, catechesis was limited to one hour per week. In the summer of 1949, the Bureau of KC PZPR drew

5 Quote from: H. Dominiczak, “Organy bezpieczeństwa PRL 1944-1990, Warsaw 1997, pgs. 99-100; A. Dziurok, Kościół katolicki na Śląsku w 1948 roku w świetle raportów Wojewódzkiego Urzędu Bezpieczeństwa Publicznego w Katowicach,” in: Ślaskie Studia Historyczno-Teologiczne 33 (2000), pgs. 366-367.

6 M. Szumiło, "Działalność redakcji Trybuny Ludu w 1955 roku w świetle raportu ambasadora sowieckiego w Warszawie," in: Res Historica 36, 2013, pgs. 302-303. 
up a declaration of loyalty to the state that catechists were required to sign at the beginning of the upcoming school year. ${ }^{7}$

In 1949, Trybuna Ludu often published articles that discussed issues concerning catechists and catechesis. The articles predominantly expressed a negative view of catechist priests, claiming that they perverted the youth. For example, one article mentions Fr. Dąbkowski, a religion teacher from Warsaw, who was sentenced to 10 years in prison for depraving young people. ${ }^{8}$ Another article refers to Fr. Talarek from Sławno, who the author claims encouraged young people to join the ranks of an illegal underground organization. ${ }^{9}$ Yet another publication names two parish priests - one from Kolbuszowa and the other from Rzeszowskie, who used corporal punishment. ${ }^{10}$ And a fourth article describes a catechist who slapped children across the face during class and spoke ill of the Association of Polish Youth (Związek Młodzieży Polskiej). ${ }^{11}$

According to Trybuna Ludu, priests abused their office while teaching in order to instill hostility towards the state. One article stated, "Under the guise of religious teachings, clergy hostile to the people's government spread slander; violated freedom of conscience; abused the pulpit and confessional as well as religion classes; terrorized youth; and threatened pupils with hell. These clergy wreaked havoc and were well on their way to starting a new inquisition." 12 Instead of educating young people in order to turn them into enlightened citizens,

History of the Church the newspaper claimed that priests led them astray. ${ }^{13}$ Trybuna Ludu reported numerous cases of hostile anti-state activities on the part of priests. According to the newspaper, Fr. Jan Szybowski, a curate and catechist from Nowy Targ, disseminated false information harmful to

$7 \quad$ H. Konopka, "Porozumienie kwietniowe 1950 roku sukces komunistów, czy klęska Episkopatu?,” in: Studia Podlaskie, vol. VIII, pgs. 120-121.

8 "Ksiądz skazany na 10 lat więzienia za deprawację nieletnich," in: Trybuna Ludu (hereafter abbreviated as TL), January, 6 1949. (All quoted articles from TL come from the local edition C - Białystok).

9 TL, August 31, 1949.

10 “Widzę źdźbło w oku...," in: TL, 28 Jan 1949.

11 "Bicie uczniów po twarzy. Metoda wychowawcza pewnych "pedagogów," in: TL, March 28, 1949.

12 A. Kubacki, "Pod płaszczykiem religii,” in: TL, January 24, 1949.

$13 \quad$ J. Cyrankiewicz, "O wynikach akcji scaleniowej zadaniach ideologicznego i organizacyjnego wzmocnienia Partii,” in: TL, April 27, 1949. 
the state and supported the robbery gang known as Ognia. In addition, he founded the illegal organization called Volcano. ${ }^{14}$

At the same time, contrary to reality, government representatives assured the people that they had no intention of removing religion from schools: "The government does not intend to limit religious freedom; there is more freedom in Poland than in other countries. We will not remove religion from schools." 15 Trybuna Ludu published articles authored by party officials who untruthfully claimed that "there is no proof for the prohibition of teaching religion." Jerzy Albrecht, the Head of the KC PZPR's Department of Propaganda, Culture, and Education, wrote the following in his article that was published in Trybuna Ludu on April 30, 1949: "The bishops' pastoral letter of April 1949 about limiting catechesis is nothing but a lie and falsifies reality." According to the politician, the facts were as follows: The church in Poland has many privileges, but it blindly obeys the Vatican, supports the underground, and wishes to return to the Middle Ages. ${ }^{16}$ On May 5, the newspaper published "Fr. Jan Polak's Open Letter Regarding the Government's Statement." The author of the letter - a "patriot priest" wrote: "... the Polish government—an authority with power granted to it by far-reaching masses of people-neither limited religious freedom in the past nor is it limiting religious freedom now. In the proposed project it still guarantees absolute freedom of religion, worship, cult, teaching, and administration." 17 On the following day, Trybuna Ludu published a letter to the editor entitled "A Reader's Comment on the Pastoral Letter" under the "From the Readers" column. In this letter, the author claimed that the Polish Bishop's pastoral letter of from April 1949 on the authorities' obstruction of religion and participation in services was a lie. To make his letter more credible, the author emphasized that he himself was Catholic. ${ }^{18}$

To provide a more "balanced" perspective Trybuna Ludu also presented "positive" examples of schools where catechist priests were not involved in any abuses. These examples also included secular schools run by the TPD - the communists' model educational institutions set

14 “Ksiądz wychował uczniów na bandytów,” in: TL, January 13, 1949.

15 "Stosunki między Kościołem a Państwem zależą od postawy kleru. Kościół korzysta w Polsce z pełnej wolności religijnej. Oświadczenie Rządu Rzeczypospolitej," in: TL, March 21, 1949.

16 J. Albrecht, “Odpowiedź wichrzycielom,” in: TL, April 30, 1949.

17 [J. Polak], "List otwarty ks. Jana Polaka w sprawie oświadczenia Rządu," in: TL, May 5, 1949. 
up and run in an atheistic spirit and in accordance with communist ideology. The education provided to students in these schools was to be free of superstitions and based on a scientific worldview. Until the end of 1949, TPD ran 14 primary and 21 secondary schools. As Trybuna Ludu reported, the planned to increase the number of TPD-run schools to accommodate approximately 40,000 children and youth. ${ }^{19}$ The TPD school experiment was part of a broader education reform program, which aimed to remove religion from the list of secondary school exit exam subjects. ${ }^{20}$

\section{"Reactionary Clergy"}

As A. Dziurok notes in his studies, the 1948 reports of the Provincial Office of Public Security in Katowice state that the Catholic Church in Poland was perceived as a serious political threat to communist authorities. According to these reports, priests criticized the communist system as well as the authorities for persecuting the Church from the pulpit. In addition, church activities, including religious instruction, were also blamed for spreading opinions that were hostile to the authorities and included political overtones. To prevent the "masses from being influenced by the clergy," those tasked with national security sought to limit the Church's negative influence on society by replacing "reactionary clergy" with "positive," "patriotic," and "progressive"

History priests who supported the communist authorities. It is believed that, of the Church during his visit with Joseph Stalin at the beginning of August 1949, the President of the Republic of Poland, Bolesław Bierut, was told that the Church would not be defeated unless the two opposing groups of priests were separated from and pitted against each other. In fact, 1948 was an important year in the "battle against clergy" who had a negative attitude toward the ruling authorities. ${ }^{21}$

In 1949, Trybuna Ludu focused a lot on reactionary and "progressive" priests. Statistically speaking, the newspaper published articles in which the clergy were presented in a pejorative light at least once a week. "Reactionary clergy" were most often referred to as AngloAmerican imperialist agents and depraved priests who strive to destabilize the state and society, rob and exploit the poor, use the pulpit to spread hostile ideas, support gangs, and do not represent the entire

\footnotetext{
19 "Szkoła TPD wychowuje młodzież na obywateli socjalistycznego państwa," in: TL, June 4, 1949. 
Church. The articles' authors focused on emphasizing these characteristics of "reactionary clergy." At the same time, the authors assure the government that they will react decisively to the enemies of public order. In January 1949, Trybuna Ludu published a speech given by Prime Minister Józef Cyrankiewicz. In the speech, he stated bluntly:

The government does not intend to interfere in the Church's internal affairs. [...] However, we will not tolerate the aggressive attitude of individual clergymen, especially from among the church hierarchy, or attempts to meddle in state affairs and in matters of secular public life..$^{22}$

The authors of Trybuna Ludu emphasized the growing awareness and political maturity of urban and rural residents. In the article "This Village Does Not Believe in Hushed Propaganda," an anonymous author remarked that a village that was experiencing a higher standard of living did not believe gossip and slander. Trybuna Ludu often published stories that included negative examples of clergy who supposedly spread gossip that was meant to put the authorities in a bad light. Among such priests was Kazimierz Cyganek from Giżycko, who allegedly encouraged the faithful to be hostile toward the government during his homilies. Similarly, Fr. Bohdanowicz from the Szyldak commune in Rychnów was accused of expressing from the pulpit negative views not only on political party topics but also about members of the PZPR. ${ }^{23}$ In an editorial from the March issue of 1949, an author refers to the Declaration on the Relationship Between the Church and the State when accusing the clergy and bishops, who, in his opinion, spread anxiety and rumors that religious freedom is being threatened. The author accused these individuals of collaborating with the reactionary underground, working for foreign agents, and committing offences and crimes. According to the author, the Church hierarchy did not support the government's position on Poland's western borders and, instead, sided with German nationalists. ${ }^{24}$ The Statement also falsely accused Bishops Stanisław Adamski and Czesław Kaczmarek of collaborating with the occupying Germans during World War II. ${ }^{25}$

Religious orders serving in Poland were also accused. According to some articles published in Trybuna Ludu, certain monks were involved in anti-state activities. The newspaper wrote about the District Court of Warsaw's ruling of January 1949, which sentenced Father Zbysław

\footnotetext{
22 “Exposé tow. Premiera Józefa Cyrankiewicza,” in: TL, January 12, 1949.

23 “Wieś nie wierzy szeptanej propagandzie,” in: TL, February 15, 1949.

24 “Państwo i Kościół,” in: TL, March 21, 1949.

25 “Stosunki między Kościołem a Państwem...,” cit., In: TL, March 21, 1949.
}

History of the Church 
Niebrzydowski, a Franciscan from Niepokalanów, to 5 years imprisonment for spreading war psychosis, distributing illegal brochures and leaflets printed by the Knight of the Immaculata in Niepokalanów. ${ }^{26}$ In these articles, female religious orders were also described as places of enslavement and humiliation. In the article entitled "I was a Nun in Magdalenka," the author describes the Sisters of Jesus the Good Shepherd's ministry running a care home for women from the margins of the society and states that these women were overworked in the field and treated inhumanly. ${ }^{27}$ Other articles included accusations of economic abuse on the part of clerics. Among others, Fr. Jan Wójcik, Chairman of the Supervisory Board and Head of the Commune Cooperative "Peasant Self-Help" in Krościenko on the Dunajec, was accused of dishonestly selling cement and appropriating over 200,000 zlotys to the cooperative's detriment at the end of January 1949. During the trial, the priest pleaded not guilty and explained that the cooperative had not suffered no financial loss. The priest was sentenced to 9 years in prison. While serving the sentence, communists invited Fr. Wójcik to cooperate with the Department of Security (Urząd Bezpieczeństwa, UB), but he rejected the offer, stating that "he would prefer to serve a second sentence than become a UB informer." ${ }^{28}$ Other articles from Trybuna Ludu described accusations against a parish priest from Żagań, who supposedly exploited poor peasants and used a horse from the United Nations Relief and Rehabilitation Administration History free of charge $;^{29}$ a Salvatorian priest, Fr. Ślusarczyk, from Kraków who of the Church was accused of conducting illegal business activities, put on trial, and sentenced to 7 years in prison; ${ }^{30}$ and Fr. Józef Kębliński, who divided up the parish benefice among the parish servicemen and did not want to pay the property tax. ${ }^{31}$

Trybuna published extensive accounts of lawsuits against priests accused of supporting the anti-communist underground, including: Kazimierz Fertak (see "Nothing for Pounds and Dollars" by L.

26 "Zakonnicy siali psychozę wojenną. Kuźnica prowokacji w Niepokalanowie," in: TL, January 27, 1949.

K. Dąbrowska, "Byłam magdalenką," in: TL, February 17, 1949.

"Ksiądz okradał Spółdzielnię 'Samopomoc Chłopska’ w Krościenku,” in: TL, January 30, 1949; F. Musiał, "Milsza mi śmierć niż współpraca," in: IPN Biuletyn 7/2009, pgs. 47-48.

“Koszty ks. proboszcza,” in: TL, February 10, 1949.

“Za potajemny ubój i garbarstwo ksiądz skazany na 7 lat więzienia,” in: TL, March 10, 1949.

31 “Bogacze wiejscy uchylają się od płacenia podatków," in: TL, June 4, 1949. 
Żebrowski); Marian Łosoś; Wacław Ortowski; Stefan Faryś; Stanisław Szymański, S. J.; Władysław Gurgacz and Jan Romanowski; Stanisław Jankesz; and priests accused of collaborating with the Germans during World War II. ${ }^{32}$

\section{"Patriotic" Priests}

The communist authorities sought to divide the Catholic Church within in order to neutralize its influence on society. In the autumn of 1949, the Provincial Committees of the PZPR began to gather materials regarding recruiting "patriot priests" from military chaplains of the Polish People's Army, former prisoners of concentration camps, and pre-war peasant activists. On September 1, President Bierut met a group of clergy, which marked the beginning of movement of "patriot priests" who supported the government. In their opinion, there were no obstacles to carrying out the mission of the priesthood within the socialist system. These priests considered themselves the followers of social-worker priests and militants similar to Fr. Szymon Konarski or Hugo Kołłątaj. The priority of "patriotic priests" was to establish direct contact with people, maintain close ties with the authorities, and submit themselves to their bishops only in spiritual matters. ${ }^{33}$ The newspaper provided examples of loyal priests who enjoyed full legal protection and care of the authorities..$^{34}$ These priests confirmed their agreement with communist authorities regarding the relationship between the Church and Polish state,$^{35}$ condemned the Holy See and Pope Pius XII and the Vatican's policy toward Poland, ${ }^{36}$ openly con-

32 Trybuna Ludu reported extensively on the priests who were tried in 1949. See articles about Fr. Fertak's trial in the February 19, 20, 26, and March 2 editions of TL; Frs. M. Łosoś, W. Ortowski, and S. Faryś - March 3, 4, 6, and September 12; Fr. S. Szymański, S. J. - June 26; Fr. W. Gurgacz - July 8, August 10, 12 , 14, and 15; Fr. J. Romanowski - August 13; Fr. S. Jankesz - September 3; and Frs. A. Hoszycki and R. Gradolewski - accused of collaboration with the Nazis - September 8, 10, and 12.

B. Kaliski, "Środowisko 'księży-patriotów' Wielkopolski i Kujaw w latach 1949-1957," in: Polska 1944/45-1989. Studia i Materiaty X/20111949-1957, pgs. 158-162.

“Stosunki między Kościołem a Państwem...," cit., in: TL, March 21, 1949.

"Ksiądz solidaryzuje się z Oświadczeniem Rządu w sprawie Kościoła,” in: TL, March 3, 1949.

36 “Weterani Powstań Śląskich potępiają politykę Watykanu," in: TL, April 13, 1949; "Jako Polak nie mogę się zgodzić z wystąpieniem Watykanu," in: TL, August 16, 1949. 
tested papal teaching, ${ }^{37}$ and promised to educate members of society to be loyal to the state. ${ }^{38}$ Trybuna extensively covered the September Congress of the Society of Fighters for Freedom and Democracy (Związek Bojowników o Wolność i Demokrację, ZBoWiD), during which the movement of pro-government priests operating within the ZBoWiD was officially inaugurated. ${ }^{39}$

\section{Preparation for Signing the 1950 Agreement}

The articles published in Trybuna Ludu in 1949 express an urgent need for the Catholic Church within Poland to sign an agreement with the communist government. The Church's situation, particularly the gradual government-imposed limitations placed on its activities, made members of the hierarchy and clergy generally reluctant to enter into negotiations with the communists. Rather, the restrictions place on the Church created an atmosphere of distrust, and members of the hierarchy questioned whether the government was sincerely considering entering into an agreement or simply forcing the Church to make a declaration of loyalty to the government of the Polish People's Republic. ${ }^{40}$ During a meeting of the Ministry of Public Security on March $23-25,1949$, officials unequivocally stated that the Church had "reacted most uncompromisingly and belligerently via the underground and foreign intelligence." ${ }^{41}$ Numerous articles were published in Trybuna

History Ludu that demanded that the clergy change their attitude toward state of the Church authorities. According to a few articles, even though bishops' pastoral letters had tried to raise concerns among the faithful by spreading information about alleged threats to religion, some members of the Church hierarchy did not oppose anti-Polish German claims and statements about the Regained Territories made by some groups associated with the Vatican. The article "The Government's Statement on the Overall Relationship between the State and the Church," which

“"Nie będę wprowadzał w życie uchwały Watykanu,” in: TL, September 1, 1949. "B. więźniowie hitlerowskich katowni," in: TL, August 23, 1949; "Będę wychowywał moich parafian na lojalnych obywateli Polski Ludowej," in: TL, August 28, 1949; "Księża-uczestnicy Zjazdu Bojowników o Wolnośći Demokrację u Prezydenta RP,” in: TL, November 12, 1949.

"Imponujący przebieg pierwszego dnia obrad Kongresu Bojowników o wolność i demokrację," in: TL, September 3, 1949.

H. Konopka, Porozumienie kwietniowe..., cit. pg. 113.

Presentation of S. Radkiewicz, in: Dokumenty do dziejów PRL, z. 9, Aparat bezpieczeństwa $w$ latach 1944-1956. Taktyka, strategia, metody, Part II, 19481949, edited by A. Paczkowski, Warsaw 1996, pg. 121. 
was published in March 1949, was followed by a massive propaganda campaign against the clergy and the faithful. From that moment forward, "spontaneous" rallies organized by the KC PZPR were held to support the government. ${ }^{42}$ The newspaper widely reported the systematic occurrence of these rallies throughout the country. The titles of these articles epitomize the expressions used by the working masses condemning "evil clergy" and expressing solidarity with the communist authorities: "Masses of People Throughout the Country Agree with the Government's Statement," "Rallies Protesting the Reactionary Clergy," "We Don't Go to Church to Hear About Politics," "The 'Marciniak' Protests Against Priests Abusing the Pulpit for Political Purposes," "Peasants' Mass Participation in Rallies in the Region of Łódź," “"The reason why the clergy's attitude hurts me is because I am a believer,' says a worker from Zieleniewski factory," and "Workers and Peasants in Rzeszów Oppose Reactionary Clergy." 43 On April 25, the President of the Republic of Poland, Bolesław Bierut, delivered a lecture on the reactionary attitude of the clergy and the state's attitude towards the Church at an assembly of the KC PZPR. Bierut stated: "[T] he Church hierarchy should decide whether it wants to take advantage of the rights and opportunities that the People's State offers or enter into an alliance with anti-national, anti-democratic, and underground forces." ${ }^{44}$ Although the Polish state and Catholic Church signed an agreement on April 14, 1950, it did not stop further repression of the Catholic Church in Poland.

\section{Conclusion}

An analysis of articles about the Catholic Church in Poland published in the newspaper Trybuna Ludu in 1949 beg the question: What was the aim of these articles and what role did the journalists who wrote them play? These articles were a means by which the Communist Party shared and spread its ideology in order to legitimize it and prevent dialogue and polemics. It is clear that the authors of the articles were officers seeking to spread propaganda that promoted the Marxist ideology determined by the Communist Party. Their task was to be at the forefront of the ideological fight to transform the mentality of the masses. They set out to defend the PZPR's party line and criticize its enemies, especially the Communist Party's greatest ideological

\footnotetext{
$42 \quad$ J. Żaryn, Kościót a władza w Polsce..., cit., pgs. 217-218.

43 Cf. TL, March 23, 1949.

$44 \quad$ B. Bierut, "Zadania Partii w walce o pokój," in: TL, April 25, 1949.
} 
opponent: the Catholic Church. The authors of the articles published in Trybuna Ludu strive to achieve the following goals set forth by the party with ideological zeal and commitment: encourage readers to side with the party, engage in building socialism and communism, and shape the readers' mentality to fit the policies of the Communist Party, which they believed was the only appropriate and acceptable institution that would ensure a better future. The faith and principles of the Catholic Church could not be accepted unless it completely submitted to the party line. The government hoped that this approach would lead to the destruction of the Catholic Church as an institution ideologically opposite to the ruling party. It is also noteworthy that the journalists of Trybuna Ludu even failed to mention several important events surrounding Primate of Poland Stefan Cardinal Wyszyński, who was mentioned in the newspaper only a few times, despite the fact that he played a decisive role in the fate of the Catholic Church in Poland after World War II.

\section{Bibliography:}

History of the Church

1. Albrecht J., "Odpowiedź wichrzycielom," in: Trybuna Ludu (hereafter abbreviated as TL), April 30, 1949.

2. "Będę wychowywał moich parafian na lojalnych obywateli Polski Ludowej,"” in: TL, August 28, 1949.

3. "Bicie uczniów po twarzy. Metoda wychowawcza pewnych "pedagogów," in: TL, March 28, 1949.

4. Bierut B., "Zadania Partii w walce o pokój," in: TL, April 25, 1949.

5. "Bogacze wiejscy uchylają się od płacenia podatków," in: TL, June 4, 1949.

6. "B. więźniowie hitlerowskich katowni," in: TL, August 23, 1949.

7. Cyrankiewicz J., "O wynikach akcji scaleniowej zadaniach ideologicznego i organizacyjnego wzmocnienia Partii," in: TL, April 27, 1949.

8. Dokumenty do dziejów PRL, z. 9, Aparat bezpieczeństwa w latach 1944-1956. Taktyka, strategia, metody, Part II, 1948-1949, edited by A. Paczkowski, Warsaw 1996.

9. Dominiczak H., Organy bezpieczeństwa PRL 1944-1990, Warsaw 1997.

10. Dudek A., Gryz C., Komuniści i Kościót w Polsce (1945-1989), Cracow 2003.

11. Dziurok A., „Kościół katolicki na Śląsku w 1948 roku w świetle raportów Wojewódzkiego Urzędu Bezpieczeństwa Publicznego w Katowicach," in: Ślaskie Studia Historyczno-Teologiczne 33 (2000).

12. Dąbrowska K., "Byłam magdalenką," in: TL, February 17, 1949.

13. "Exposé tow. Premiera Józefa Cyrankiewicza," in: TL, January 12, 1949.

14. "Imponujący przebieg pierwszego dnia obrad Kongresu Bojowników o wolność i demokrację," in: TL, September 3, 1949.

15. "Jako Polak nie mogę się zgodzić z wystąpieniem Watykanu," in: TL, August 16, 1949. 
16. Kaliski B., "Środowisko 'księży-patriotów' Wielkopolski i Kujaw w latach 1949-1957," in: Polska 1944/45-1989. Studia i Materiaty X/20111949-1957.

17. Karp H., Dziennikarz w systemie mediów totalitarnych Polski Ludowej, in: "Media - Kultura - Społeczeństwo," 9-10 (2014-2015).

18. Kersten K., Narodziny system wtadzy. Poland 1943-1948, Poznań 1990.

19. Konopka H., "Porozumienie kwietniowe 1950 roku sukces komunistów, czy klęska Episkopatu?," in: Studia Podlaskie, vol. VIII.

20. "Koszty ks. proboszcza," in: TL, February 10, 1949.

21. "Ksiądz okradał Spółdzielnię 'Samopomoc Chłopska’ w Krościenku,” in: TL, January 30, 1949.

22. "Ksiądz skazany na 10 lat więzienia za deprawację nieletnich," in: TL, January, 61949.

23. "Ksiądz solidaryzuje się z Oświadczeniem Rządu w sprawie Kościoła," in: TL, March 3, 1949.

24. "Ksiądz wychował uczniów na bandytów," in: TL, January 13, 1949.

25. "Księża - uczestnicy Zjazdu Bojowników o Wolność i Demokrację u Prezydenta RP," in: TL, November 12, 1949.

26. Kubacki A., "Pod płaszczykiem religii," in: TL, January 24, 1949.

27. Musiał F., "Milsza mi śmierć niż współpraca," in: IPN Biuletyn 7/2009.

28. "Nie będę wprowadzał w życie uchwały Watykanu," in: TL, September $1,1949$.

29. "Ofensywa kleru a nasze działania," in: Dokumenty do dziejów PRL. Aparat bezpieczeństwa w latach 1944-1956. Taktyka, strategia, metody, Part I, Years 1945-1947, edited by J. Żaryn, Warsaw 1994.

30. "Państwo i Kościól," in: TL, March 21, 1949.

31. [Polak J.], "List otwarty ks. Jana Polaka w sprawie oświadczenia Rządu," in: TL, May 5, 1949.

32. "Stosunki między Kościołem a Państwem zależą od postawy kleru. Kościół korzysta w Polsce z pełnej wolności religijnej. Oświadczenie Rządu Rzeczypospolitej," in: TL, March 21, 1949.

33. "Stosunki między Kościołem a Państwem...," cit., In: TL, March 21, 1949.

34. "Szkoła TPD wychowuje młodzież na obywateli socjalistycznego państwa," in: TL, June 4, 1949.

35. Szumiło M., "Działalność redakcji Trybuny Ludu w 1955 roku w świetle raportu ambasadora sowieckiego w Warszawie," in: Res Historica 36, 2013.

36. "Weterani Powstań Śląskich potępiają politykę Watykanu," in: TL, April $13,1949$.

37. "Widzę źdźbło w oku...," in: TL, 28 Jan 1949.

38. "Wieś nie wierzy szeptanej propagandzie," in: TL, February 15, 1949.

39. [Wysocki K.], "Wypowiedź czytelnika o Liście Pasterskim," in: TL, May $6,1949$.

40. "Zakonnicy siali psychozę wojenną. Kuźnica prowokacji w Niepokalanowie," in: TL, January 27, 1949.

41. "Za potajemny ubój i garbarstwo ksiądz skazany na 7 lat więzienia," in: TL, March 10, 1949.

42. Żaryn J., Kościót a władza w Polsce (1945-1950), Warsaw 1997. 